\title{
Article
}

\section{Protection of Non-Trade Values in WTO Appellate Body Jurisprudence: Exceptions, Economic Arguments, and Eluding Questions}

Andersen, Henrik

Available at http://clok.uclan.ac.uk/13394/

Andersen, Henrik (2015) Protection of Non-Trade Values in WTO Appellate Body Jurisprudence: Exceptions, Economic Arguments, and Eluding Questions. Journal of International Economic Law, 18 (2). pp. 383-405.

It is advisable to refer to the publisher's version if you intend to cite from the work. http://dx.doi.org/10.1093/jiel/jgv020

For more information about UCLan's research in this area go to http://www.uclan.ac.uk/researchgroups/ and search for < name of research Group>.

For information about Research generally at UCLan please go to http://www.uclan.ac.uk/research/

All outputs in CLoK are protected by Intellectual Property Rights law, including Copyright law. Copyright, IPR and Moral Rights for the works on this site are retained by the individual authors and/or other copyright owners. Terms and conditions for use of this material are defined in the policies page. 


\title{
Non-Trade Values in WTO Appellate Body Jurisprudence
}

\author{
Henrik Andersen*
}

\begin{abstract}
The article suggests that the constitutional scope of the WTO leaves a wide space for the Appellate Body to protect non-trade values. That has to some extent materialized in Appellate Body practice; human health and environment are attaining general protection across the WTO treaties. They are recognised as vital and important values by the Appellate Body and they are not just protected as exceptional policy objectives to the trade argument; they are part of the trade argument. It is, however, still unsettled how other vital values, like those which can fall under peremptory norms, can be protected by the Appellate Body and whether its current approach provides the necessary tools for their protection.
\end{abstract}

\section{Introduction}

The Appellate Body ( $\mathrm{AB}$ ) of the World Trade Organization (WTO) often takes a central role in deciding between trade and non-trade values. Trade values encompass ideas of economic welfare and efficiency where the market serves as means to the ends. The market might support non-trade values like protection of the environment, animal rights, religious ethics, social rights, labour rights, human health etc. For example, organic products can be allocated through the market and without trade obstacles reach new territories to the benefit of inter alia consumers, human health, and the environment. ${ }^{1}$ Challenges occur when trade and non-trade values collide; when certain types of products are unwanted on a market because of their incompatibilities with non-trade values. According to the $\mathrm{AB}$, the Agreement Establishing the World Trade Organization (WTO Agreement), as a whole, reflects 'the balance struck by WTO Members between trade and nontrade-related concerns." ${ }^{2}$ That balance is guided by the language of the respective WTO treaties. According to the $\mathrm{AB}$, the non-trade values must be covered by one of the non-trade policy

\footnotetext{
* Lecturer at Lancashire Law School and Visiting Lecturer at Copenhagen Business School, Law Department. For comments please contact henriklaw@yahoo.com.

${ }^{1}$ In this article, 'value' is used in a broad sense to denote the 'principles or moral standards held by a person or social group; the generally accepted or personally held judgement of what is valuable and important in life.' cf. "value, n." OED Online. Oxford University Press, June 2014. Web. 21 June 2014. This definition will work for the purpose of this article. The AB itself distinguishes between 'trade' and 'non-trade' values without further clarification of the concepts. It is not the aim to engage into a philosophical or sociological discussion about the concept of 'value'. However, it is important to note that for this article, the concept of 'non-trade value' does not imply that it is completely detached from trade but that the fundamental elements of the value have no connection with trade. For example, even though fair trade products can be sold on the market based on consumer choices, the fundamental value behind the fair trade concept is poverty reduction and sustainable development. See for example the preamble of the Constitution of Fairtrade Labelling Organizations International e.V, adopted on: 25 May 2007, amended on 14 November 2013.

${ }^{2}$ WTO Appellate Body Report, China - Measures Related to the Exportation of Various Raw Materials (China - Raw Materials), joined cases WT/DS394, 395, and 398/AB/R, adopted 22 February 2012, para. 306.
} 
objectives in the WTO treaties, like Art. XX of the General Agreement on Tariffs and Trade 1994 (GATT 1994), in order to be accepted.

This article discusses the $\mathrm{AB}$ approach to non-trade values. The article claims that the $\mathrm{AB}$ has developed different routes to protect non-trade values either through explicit exceptions in the WTO treaties, through economic arguments in the national treatment assessment, and through economic arguments in subsidy determinations. The $\mathrm{AB}$ has in particular protected human health, which is considered to be a vital value, and the environment, which is an important value. Questions still remain how vital values, like anti-slavery, are protected in the WTO system. The article commences (II) by providing an overview of the market-oriented basis of the WTO and the constitutional limits of the AB. Next, (III) the article discusses overlaps between the WTO and other regimes where nontrade values have a stronger footing. Section (IV) concerns how the AB protects non-trade values through explicit exceptions in WTO law with focus on GATT 1994, Art. XX. Section (V) focuses on situations where the $\mathrm{AB}$ has accepted non-trade values without explicit exceptions in the WTO treaties. Finally, (VI) the article considers some implications of the AB approach.

\section{The Market-Oriented Basis and Constitutional Limits}

After World War II, new institutional arrangements were designed to replace the politically and institutionally fragile League of Nations and provide everlasting peace. Since World War I and II had been fuelled by economic nationalism and protectionism, the opening of the international markets for trade through the International Trade Organization (ITO) was intended to be a tool to reach global peace and economic welfare. ${ }^{3}$ In market economy theory, ${ }^{4}$ the market is considered the best instrument to achieve an efficient allocation of resources given full information, profit maximization, and rational agents, ${ }^{5}$ and where a reduction of tariffs and elimination of trade barriers

\footnotetext{
${ }^{3}$ John H. Jackson, Sovereignty, the WTO, and Changing Fundamentals of International Law, (Cambridge: Cambridge University Press, 2006) 85.

${ }^{4}$ There are different types of market economy perspectives on how and when the public should gain ownership over resources as well as when to interfere in the market. For example China works with a 'socialist market economy' with multiple state-owned companies, cf. Art. 5 - 11 of the Constitution of the People's Republic of China whereas the EU works with a competitive social market economy with a high level of social protection, cf. Art. 3(3) of the EU Treaty.

5 'Efficiency' is in itself a contested concept. Pareto efficiency provides that the efficient allocation of resources is a state where no further allocation can take place without making minimum one person worse off. Another efficiency approach is Kaldor/Hicks which allows for a state where one or more persons are made worse of due to the change in the allocation of resources provided that the gain from this re-allocation is higher than the losses for those persons who are made worse off. Put differently; that the gain of the winners of the re-allocation of the resources is high enough to compensate the losses of the losers. See Richard A. Posner, The Economics of Justice, (Cambridge, Massachusetts and London, England: Harvard University Press, 1983) 88-115.

Neoclassical theory works with assumptions of self-interest, rationality and full information of the agents in the market. Property rights are taken for granted. However, the neoclassical approach does not answer questions about law, organizations etc. See instead New Institutional Economics' (NIE) focus on institutions, like law and organizations, and on the costs of the market; i.e. transaction costs. See for example R. H. Coase, 'The Nature of the Firm', 4 (16) Economica 386 (November 1937). NIE works with bounded rationality and transaction costs, like costs of information and costs of defining property rights. See also Eirik G. Furubotn and Rudolf Richter, Institutions and Economic Theory - The Contribution of the New Institutional Economics, $2^{\text {nd }}$ ed. (Michigan: The University of Michigan Press, 2010).
} 
lead to comparative advantages for the states. ${ }^{6}$ However, the market does not always ease the path to efficiency. Market failures, like externalities or asymmetrical information, reduce the efficient outcome. An externality is a by-product of production and can be positive, i.e. providing benefits for others than the agent producing the externality, and/or negative, i.e. imposing costs on others than the agent causing the negative externality. ${ }^{7}$ Governments should interfere into the market in order to eliminate those deficiencies and indirectly protect other values if the social costs of their reduction or elimination outweigh the private gain. For example pollution of water has high social costs and should be regulated accordingly. ${ }^{8}$

The General Agreement on Tariffs and Trade (GATT) of 1947 was designed to be a temporary arrangement until the realization of the ITO. Since the ITO never materialized, GATT became the major international trade body administrating international trade rules for nearly 50 years. The aims of GATT 1947 were to raise the standard of living, ensuring full employment and a large and steadily growing volume of real income and effective demand, developing the full use of the world resources, and expanding the production and exchange of goods. In order to open international markets, GATT 1947 contained 5 basic trade principles; the Most-Favoured-Nation principle requiring GATT members not to discriminate between the trading partners; the National Treatment principle where GATT Members must not discriminate between domestic and foreign products once the foreign products have crossed the custom barrier; principles of market access where tariffs are reduced and quantitative restrictions eliminated; principles of fair competition where dumped prices are condemned and some subsidies prohibited; transparency where GATT Members must publish trade rules and administer them in a uniform, impartial and reasonable manner and provide judicial, arbitral or administrative tribunals to review administrative trade practices. As the market ideal could be at odds with national non-trade values like social policies, cultural underpinnings, public morality etc., GATT 1947 provided exceptions where the GATT Members could pursue national non-trade policies to the detriment of the market ideal. ${ }^{9}$

The line between trade and non-trade values gave rise to disputes between the GATT members. To ensure third party dispute resolution, a panel of experts would be established and provide recommendations concerning the interpretation of GATT 1947. The recommendation would only attain a binding effect if consensus was reached by all the GATT Members. However, panels developed a judicialized approach and GATT became stretched between traditional intergovernmentalism and the evolving rule-oriented legal discourse. ${ }^{10}$ As GATT was insufficient to

\footnotetext{
${ }^{6}$ See about comparative advantages; Alan J. Sykes, 'Comparative Advantage and the Normative Economics of International Trade Policy', 1 (1) Journal of International Economic Law 49 (1998).

${ }^{7}$ See also R. H. Coase, 'The Problem of Social Costs', 3 The Journal of Law and Economics 1 (October 1960), where he suggests that in a world with no transactions costs, all externalities will be internalized.

${ }^{8}$ There are also debates about subsidies whether they are economically sound or just a barrier to trade. See for example Simon Lester, 'The Problems of Subsidies as a Means of Protectionism: Lessons from the WTO EC - Aircraft Case', 12 (2) Melbourne Journal of International Law 1 (2011) and Alan J. Sykes, 'Comparative Advantage and the Normative Economics of International Trade Policy’, 1 (1) Journal of International Economic Law 49 (1998) at 80-81.

${ }^{9}$ For example, GATT 1947 (now 1994), Art. XX contains exceptions.

${ }^{10}$ See for an overview; John H. Jackson, 'The Legal Meaning of a GATT Dispute Settlement Report', in John H. Jackson, The Jurisprudence of GATT \& the WTO, (Cambridge: Cambridge University Press, 2000), 118-132
} 
respond to the steady increase in cross-border transactions and growing demand of legal certainty, the WTO was negotiated to be the solution. The multilateral nature of GATT and its marketoriented legacy continued in the WTO but it had a wider scope of aims than GATT, including sustainable development and protection and preservation of the environment. The WTO also strengthened the dispute settlement system by creating the DSB and the AB and by abandoning the veto right.

The institutional changes have led to debates about the possible constitutionalisation of the WTO. ${ }^{11}$ In contrast to a traditional, intergovernmental approach, seeing the WTO through constitutional lenses leaves room for the $\mathrm{AB}$ to include in its methodology both a higher level of abstraction, where competing and overlapping values can be weighed and balanced in light of constitutional principles like rule of law and proportionality, and a temporal flexibility where concepts of law, rights and obligations can be understood in light of contemporary understandings. A constitutional approach raises both conceptual and normative questions. First, scholars debate whether the WTO qualifies as a constitutional system which ultimately depends on the definition of 'constitution' and its applicability to functional communities. ${ }^{12}$ For example, some scholars provide abstract definitions of 'constitutions' and 'constitutionalization' which encompass functional communities. ${ }^{13}$ Other scholars find that the WTO lacks fundamental constitutional traits like the ability to make secondary law and it has democratic deficits. ${ }^{14} \mathrm{~A}$ third approach is forwarded by Walker where the question of constitutionalisation is a matter of degree. The WTO can be conceived in constitutional terms even if some of the constitutional factors are underdeveloped. ${ }^{15}$ Secondly, a constitutional narrative on meta-level, i.e. beyond the scope of the nation-state, calls into question the traditional Westphalian assumptions of international law as a system of sovereign states with exclusive authority for rule creation, interpretation, and enforcement and where the reach of the constitution is

\footnotetext{
${ }^{11}$ See for example Neil Walker, 'The EU and the WTO: Constitutionalism in a New Key', in De Búrca and Scott (eds), The EU and the WTO: Legal and Constitutional Issues, (Oxford: Hart Publishing, 2001), 31-57; Jeffrey L. Dunoff, 'Constitutional Conceits: The WTO's 'Constitution' and the Discipline of International Law', 17 (3) The European Journal of International Law, 647 (2006); Joel P. Trachtman, 'The Constitutions of the WTO’, 17 (3) The European Journal of International Law, 623 (2006); See for a number of contributors and discussions in Christian Joerges and Ernst-Ulrich Petersmann (eds.), Constitutionalism, Multilevel Trade Governance and International Economic Law, $2^{\text {nd }}$ ed., (Oxford: Hart Publishing, 2011).

${ }^{12}$ Alec Stone Sweet, 'Constitutionalism, Legal Pluralism, and International Regimes', 16 (2) Indiana Journal of Global Legal Studies, 621 (2009). See also Jessica Lawrence, 'Contesting constitutionalism: Constitutional discourse at the WTO', 2:1 Global Constitutionalism, 63 (2013) where the question of 'constitutionalization' of the WTO is a discursive contest.

${ }^{13}$ For example, Alec Stone Sweet has defined constitution as 'a body of meta-norms, those higher-order legal rules and principles that specify how all other lower-order legal norms are to be produced, applied, enforced, and interpreted,' ibid at 626. See for a more normative definition Ernst-Ulrich Petersmann, 'International Economic Law, 'Public Reason', and Multilevel Governance of Interdependent Public Goods', 14 (1) Journal of International Economic Law, 23 (2011) at 53. According to Petersmann, a constitution - even the functionally limited community constitutions, like the WTO - serves to protect rule of law and justice.

${ }^{14}$ See for example Peter Holmes, 'The WTO and the EU: Some Constitutional Comparisons' in De Búrca and Scott (eds), The EU and the WTO: Legal and Constitutional Issues, (Oxford: Hart Publishing, 2001), 59-80

${ }^{15}$ See for example Neil Walker's 7 factors of constitutionalism; constitutional mature discourse, authority, jurisdiction, interpretative autonomy, institutional capacity, citizenship, and representation. Those factors can be applied on nonstate polities and they are not all-or-nothing terms but must rather be understood with nuance and gradation. Neil Walker, above n 11, 31-57.
} 
limited by geographical territories. International law is here based on consent and practice between states. By adopting a constitutional narrative, the traditional international system is re-mapped. It implies other actors than the states in international rule creation, interpretation and enforcement, and it elevates certain principles of law to a supreme level in international matters. This writer takes the position that international organizations, like the WTO, have constitutional traits, ${ }^{16}$ where the WTO Agreement is the constitutional basis for the AB. It provides the constitutional equilibrium between the various WTO organs and the WTO Members, and it prevails in case of conflict with all other multilateral treaties which are annexed to the WTO Agreement. ${ }^{17}$ Even though the WTO does not have a high level of constitutional maturity and with only limited citizen representation, it has de facto authority to define its jurisdictional and interpretative space. ${ }^{18}$ The WTO Members are influential in the interpretation of the WTO treaties through their representation in the Ministerial Conference and the General Council which have exclusive authority to adopt final interpretations of the WTO Agreement and all the multilateral treaties by three-fourth majority. ${ }^{19}$ However, that tool is rarely applied. ${ }^{20}$ Instead panels and AB are often used to provide interpretations of the WTO treaties and to strike the balance between trade and non-trade values. The mandate of panels and the AB follows from the WTO Agreement and is clarified in the Dispute Settlement Understanding (DSU). They must preserve the rights and obligations of the WTO Members under the various WTO agreements; they must clarify the provisions of those agreements in accordance with customary rules of interpretation of public international law; and they cannot add to or diminish the rights and obligations provided in the covered agreements. ${ }^{21}$ Within those constraints the $\mathrm{AB}$ has made a clear mark in defining both its constitutional and interpretative space. It has developed its own legal discourse; it develops legal argumentations beyond the arguments of the disputing parties; ${ }^{22}$ it examines national law's compliance with WTO law ${ }^{23}$ and even though AB case-law formally does not have the character of 'final interpretations', which would be crossing the line into Ministerial Conference and General Council territory, the decisions serve de facto as a source of law-like tool and are applied in the legal argumentation by the AB, the panels and the WTO

\footnotetext{
${ }^{16}$ Ibid. For example, the UN has constitutional traits like the authority of the UN Security Council, the ILO has also constitutional traits like, for example, the representation of employees and employers in the rule creation.

${ }^{17}$ WTO Agreement, Art. XVI (3).

${ }^{18}$ Neil Walker, above n 11.

${ }^{19}$ WTO Agreement, Art. IX.

${ }^{20}$ It has been used to protect non-trade values like the 2001 Doha Declaration where human health and access to medicine for all justified limitations on intellectual property rights in developing and least-developed countries. See Declaration on the TRIPS Agreement and Public Health, Ministerial Conference, Fourth Session, Doha 9-14 November 2001, WT/MIN(01)/DEC/2 of 20 November 2001.

${ }^{21}$ DSU, Art. 3.2.

${ }^{22}$ See WTO Appellate Body Report, European Communities - Measures Concerning Meat and Meat Products (Hormones) (EC - Hormones), WT/DS26 and 48/AB/R, adopted 13 February 1998, para 156; WTO Appellate Body Report, United States - Import Measures on Certain Products from the European Communities (US - Certain EC Products), WT/DS165/AB/R, adopted 10 January 2001, para 123, and WTO Appellate Body Report, Canada Certain Measures Affecting the Renewable Energy Generation Sector (Canada - Renewable Energy) WT/DS412/AB/R and Canada - Measures Relating to the Feed-in Tariff Program (Canada - Feed-In Tariff Program), WT/DS426/AB/R, adopted 24 May 2013, paras 5.214-5.215.

${ }^{23}$ WTO Appellate Body Report, United States - Sunset Review of Anti-Dumping Duties on Corrosion-Resistant Carbon Steel Flat Products from Japan (US - Corrosion-Resistant Steel Sunset Review), WT/DS244/AB/R, adopted 9 January 2004, para. 82.
} 
Members. ${ }^{24}$ In the view of the $\mathrm{AB}$, 'absent cogent reasons, an adjudicatory body will resolve the same legal question in the same way in a subsequent case. ${ }^{25}$ That argument is a corner-stone of a constitutional society based on rule of law and its implied principle of legal certainty. Stone Sweet has even suggested that the $\mathrm{AB}$ acts as a constitutional court. ${ }^{26}$ However, the role of the $\mathrm{AB}$ is not unproblematic; it must decide in a grey-zone of overlaps between WTO law and law of other international regimes.

\section{Overlaps between the WTO and Other Regimes}

Non-trade values have stronger roots in other international organizations than the WTO. For example, the United Nations (UN) aims at saving future generations from war, reaffirming faith in human rights and equal rights between men and women and big and small nations, providing frameworks upon which justice and freedom can be protected, and promoting social progress and better standards of life in larger freedom; the World Health Organization (WHO) aims at promoting and protecting health of all peoples; the International Labour Organization (ILO) promotes and protects social justice for workers and protects children. Protection of such aims and values may not be compatible with the WTO unless they have explicit basis under one of the exceptions. The multilevel and overlapping nature of the functional communities generates normative challenges for the AB. A rejection of other international treaties would put the WTO Members at odds with their other international commitments. Yet, the map of international organizations shows an uneven landscape of constitutional, political and legal maturity. Their legal or interpretative autonomy are at different levels; some sectors have a more intergovernmental character than others; and their legal and constitutional cultures are different. This seeming disorder of international organizations with different aims, values and legal and constitutional maturity has led to theoretical and normative debates about norm hierarchy and relations between the various regimes. Legal pluralists suggest a heterarchy between those regimes with no overall constitutional or legal solution to the disorder or conflicts between overlapping orders. Rather it seeks political solutions in this fragmented world. ${ }^{27}$ Constitutional pluralists, on the other hand, search for meta-constitutional principles which are

\footnotetext{
${ }^{24}$ Occasionally, the EU Courts also refer to AB reports; see for example Case C-414/11, Daiichi Sankyo and SanofiAventis Deutschland (2013) ECR I-0000, para. 80. However, there are some reservations as the Court has stated that it alone has jurisdiction to determine whether an EU act is unlawful, see for example Case C-533/10, CIVAD (2012) ECR I-0000, para. 40, and WTO treaties do not have direct effect, see for example Joined Cases C-120/06 P and C-121/06 P, FIAMM and Others $v$ Council and Commission (2008) ECR I-6513, paras. 127-133.

${ }^{25}$ See WTO Appellate Body Report, United States - Final Anti-Dumping Measures on Stainless Steel from Mexico (US - Stainless Steel (Mexico)), WT/DS344/AB/R, adopted 20 May 2008, para. 160. See also the comment by the AB in WTO Appellate Body Report, United States - Tax Treatment for "Foreign Sales Corporations" (US - FSC), WT/DS108/AB/R, adopted 20 March 2000, footnote 127, where it clearly distinguishes between the interpretations provided by a Ministerial Conference and General Council under Art. IX.2 of the WTO Agreement and an interpretation provided by the $\mathrm{AB}$.

${ }^{26}$ Alec Stone Sweet, above n 12, at 642.

${ }^{27}$ See for example Nico Krisch, 'The Case for Pluralism in Postnational Law', in Gráinne De Búrca \& J.H.H. Weiler (eds.), The Worlds of European Constitutionalism, (Cambridge: Cambridge University Press, 2012), 203-261; Martti Koskenniemi and Päivi Leino, 'Fragmentation of International Law? - Postmodern Anxieties', 15 (3) Leiden Journal of International Law 553 (2002).
} 
common ground for the competing constitutional regimes. ${ }^{28}$ Constitutional pluralism does not suggest a hierarchical governance structure as the institutions must defer to the constitutional boundaries of the overlapping constitutions. Instead meta-constitutional principles develop through coordinated efforts by international institutions like international courts. ${ }^{29}$

In practice, the constitutional borders and the interrelationship between the WTO and other international organizations are not easily drawn. The UN Charter provides that it prevails in case of conflict with other treaties. ${ }^{30}$ It will not be in conflict with WTO law if a WTO Member pursues obligations under the UN Charter for the maintenance of international peace and security. ${ }^{31}$ For example, if the UN Security Council passes a resolution imposing economic sanctions towards a state, which violates international peace or security, WTO Members can comply with the resolution without violating WTO law. ${ }^{32}$ Yet it remains unclear whether the UN Charter will prevail beyond the maintenance of international peace and security obligation. ${ }^{33}$ For example, even though the preamble of the UN Charter refers to human rights, and similar support can be found in the preamble of the Vienna Convention on the Law of Treaties (VCLT), which serves as the interpretative basis for the $\mathrm{AB}$, the question is whether human rights can be transplanted into the

${ }^{28}$ The conceptualization of constitutional pluralism and its normative dimension lacks clarity. See for example Matej Avbelj and Jan Komárek, 'Four Visions of Constitutional Pluralism', 4 (3) European Constitutional Law Review 524 (2008). See also Neil Walker, 'The Idea of Constitutional Pluralism', 65 The Modern Law Review 317 (2002); and Ernst-Ulrich Petersmann, International Economic Law in the $21^{\text {st }}$ Century - Constitutional Pluralism and Multilevel Governance of Interdependent Public Goods, (Oxford and Portland, Oregon: Hart Publishing 2012). Alec Stone Sweet has suggested two approaches of 'constitutional pluralism'; one sees the multilevel constitutions as pluralist and disordered but through the interaction of the various constitutional orders, some overall system will develop. The other type is a 'higher law' approach where the outset is some higher meta-norms, like human rights and rule of law, which guide the pluralistic constitutional orders when they interfere. See Alec Stone Sweet, above n 12 at 632.

${ }^{29}$ See for example the European Court of Human Rights (ECHR) referring to the International Court of Justice (ICJ), like the recent case, Ališić and Others v. Bosnia and Herzegovina, Croatia, Serbia, Slovenia and the former Yugoslav Republic of Macedonia (merits and just satisfaction), no. 60642/08, § 40, ECHR 2012. But also its inclusion of other treaties, like The Agreement on Trade-Related Aspects of Intellectual Property Rights (TRIPS). In Anheuser-Busch Inc. v. Portugal (merits and just satisfaction) [GC], no. 73049/01, Reports of Judgments and Decisions 2007-I, which concerned Art. 1 of the European Convention on Human Rights, TRIPS served as relevant international law although the Grand Chamber did not refer to TRIPS. Laurence R. Helfer has suggested that the language of the Grand Chamber in the specific case resemblances the language of TRIPS and that TRIPS may serve as inspiration for the ECHR; Laurence R. Helfer, 'The New Innovation Frontier? Intellectual Property and the European Court of Human Rights', 49 (1) Harvard International Law Journal 1 (2008), at 40-42. See also reference to the WTO and US - Shrimps in the joint dissenting opinion of judges David Thór Björgvinsson, Vučinić and Nussberger in Herrmann v. Germany (merits and just satisfaction) [GC], no. 9300/07, ECHR 2012.

${ }^{30}$ Art. UN Charter, Art. 103.

${ }^{31}$ GATT 1994, Art. XXI (c), GATS, Art. XIV bis.1 (c), and TRIPS, Art. 73 (c).

${ }^{32}$ Mostly the sanctions by the Security Council concerns financial assets or weapon embargos although on occasion an export prohibition has been applied on luxury goods, see for example UN Security Council Resolution 1874, S/RES/1874 (2009), in combination with Security Council Resolution 1718, S/RES/1718 (2006) which concerned a non-WTO Member, North Korea.

${ }^{33}$ See for example the discussion about Westphalian versus Eastphalian approaches to concepts of 'universal law', Andrew Coleman and Jackson Nyamuya Maogoto, "Westphalian" Meets "Eastphalian" Sovereignty: China in a Globalized World', 3 (2) Asian Journal of International Law 237 (2013). In practice, the European Court of Justice has shown dualist traits towards Security Council Resolutions concerning peace and security if they do not conform to fundamental rights. See Kadi and Al Barakaat International Foundation v Council and Commission, Joined Cases C-402/05 P and C-415/05 P, (2008) ECR I-6351, paras. 282-285. See for a discussion and critique of the EU Court; Gráinne de Búrca 'The European Court of Justice and the International Legal Order After Kadi', 51 (1) Harvard International Law Journal 1 (Winter 2010). 
WTO system and whether they have a special status in WTO law. The WTO treaties do not explicitly refer to human rights although it is debated whether human rights can fall under public morals exceptions. ${ }^{34}$ A human rights dimension in the WTO also faces other challenges. Human rights do not have a clear definition and they are spread across various treaties, constitutions, and bill of rights on international, regional, and national levels where they are subject to cultural, political, ethical, economic, and social differences. ${ }^{35}$ Most international treaties are not ratified by all states due to those differences. ${ }^{36}$ In addition, human rights protect individuals against states; they do not create rights for states. Moreover, WTO law has its Members as subjects, and only members have locus standi in the DSB, i.e. individuals cannot make human rights claims before panels and AB. ${ }^{37}$ Nevertheless, it may be asked whether a WTO Member can include human rights considerations as legitimate reasons for not complying with the basic trade principles against another state if that particular state violates human rights standards. Notwithstanding the disagreements on the scope and definitions of 'human rights', 'fundamental rights', and 'peremptory norms,' most states recognize the 'inherent dignity and of the equal and inalienable rights of all members of the human family is the foundation of freedom, justice and peace in the world' through their ratifications of the International Covenant on Civil and Political Rights (ICCPR) and/or the International Covenant on Economic, Social and Cultural Rights (ICESCR) and they are bound by those human rights which qualify as peremptory norms. ${ }^{38}$ Accordingly, some human rights are recognized on meta-level and should not be ignored by the $A B$ even though their concrete content are subject to multidimensional understandings. ${ }^{39}$ Furthermore, the overlaps between WTO law and human rights law might to some extent be solved through WTO law itself. At the 1996 WTO Ministerial Conference in Singapore, the Ministerial Conference adopted a Declaration where it renewed its commitment to 'the observance of internationally recognized core labour standards' where the ILO is the 'competent body to set and deal with these standards'. ${ }^{40}$ The

\footnotetext{
${ }^{34}$ See more below in section IV.

35 See for example the 'margin of appreciation' developed by the ECHR where inter alia cultural, historical, ethical differences between the European States are accepted. For example, S.A.S. v. France (merits and just satisfaction) [GC], no. 43835/11, ECHR 2014, concerned a French ban on the wearing of full-face veils in public places in France. It was claimed that the ban violated the right to freedom of religion of the European Convention on Human Rights, Art. 9. According to the ECHR, it was a choice of 'society' where France protected the principle of interaction between individuals where full-face veils could be a limitation on social communication. The ECHR recognised the lack of European consensus among the States concerning such a ban and referred to Leyla Şahin v. Turkey (merits and just satisfaction [GC], no. 44774/98, Reports of Judgments and Decisions 2005-XI, where it had stated that such rules would differ from country to country based on national traditions. Hence France had a wide margin of appreciation and the ECHR found that France had not violated the Convention. See in particular paras. 132-159.

36 Theodore Meron, 'On a Hierarchy of International Human Rights', 80 (1) The American Journal of International Law 1 (January, 1986). See also Marie-Bénédicte Dembour, 'What Are Human Rights? Four Schools of Thought', 32 Human Rights Quarterly 1 (2010).

${ }^{37}$ Human rights views could be expressed by NGOs who may submit amicus curae briefs.

${ }^{38}$ See Art. 53 of the VCLT and the position taken by the International Law Commission in its Report of the International Law Commission on the Work of Its $34^{\text {th }}$ Session, Yearbook of the International Law Commission, (1982), vol. II, Part Two, p. 56.

${ }^{39}$ Theodore Meron, above n 36.

${ }^{40}$ SINGAPORE WTO MINISTERIAL 1996: MINISTERIAL DECLARATION. WT/MIN(96)/DEC, 18 December 1996.
} 
ILO's core principles are enshrined in 8 fundamental ILO conventions. ${ }^{41}$ One of them is the Worst Forms of Child Labour Convention which provides that child slavery is prohibited and the ILO Members must sanction conduct which is incompatible with the convention. ${ }^{42}$ Thus an importing state may penalize a company if its imported products are produced in violation of the convention without violating WTO law. ${ }^{43}$ Besides the Singapore Ministerial Declaration, there may be support in GATT 1994, Art. XX (a) for such position, see more in IV.

As the constitutional borders between the WTO and other regimes, like the UN and the ILO, are rather aqueous instead of solid rock, and with the requirement in DSU, Art. 3.2 to clarify the WTO treaties in accordance with the customary rules of interpretation of public international law, it can be argued that the $\mathrm{AB}$ has sufficient interpretative space to include other international treaties, like the ICCPR, the ICESCR, ILO Conventions and numerous environmental treaties, when they overlap with WTO law. The AB itself refers to Art. 31 and Art. 32 of the VCLT as customary rules of interpretation of public international law. Art. 31(1) provides that a treaty must be interpreted in good faith 'in accordance with the ordinary meaning to be given to their terms in their context and in light of its object and purpose.' Art. 31(3)(c) requires that '[t]here shall be taken into account, together with the context: (...) Any relevant rules of international law applicable in the relations between the parties. ${ }^{44}$ Thus the normative environment must be taken into account when a treaty provision is interpreted. ${ }^{45}$ The $\mathrm{AB}$ has stated that interpretation after Art. 31 of the VCLT is a 'holistic exercise' and that WTO treaties are 'not to be read in clinical isolation from public international law.' 46 According to the $\mathrm{AB}$ this wider context consists of 'any relevant rules of international law' corresponding to the catalogue of sources applicable to the International Court of justice (ICJ). ${ }^{47}$ In EC and Certain Member States - Large Civil Aircraft, the AB stated that Art. 31(3)(c) reflects the principle of systemic integration and requires that any relevant rule of international law between the parties must be taken into account. The $A B$, however, expressed some caution about including other international treaties which not all the WTO Members are parties to. According to the AB, it must strike a balance between the respective WTO Members' international

\footnotetext{
${ }^{41}$ See for example Henrik Andersen, 'Core Workers' Rights as Constitutional Principles in the WTO', in Fejø, Neergaard, Tvarnø and Ølykke (eds), Festskrift Liber Americum et Amicorum in Honour of Ruth Nielsen, (Copenhagen: Jurist og Økonomforbundets Forlag, 2013), 31-59 at 41.

${ }^{42}$ See the Worst Forms of Child Labour Convention, Art. 1.

${ }^{43}$ See for example Shima Baradaran and Stephanie Barclay, 'Fair Trade and Child Labour', 43 (1) Columbia Human Rights Law Review 1 (2011) at 21-23.

${ }^{44}$ See for more thorough discussions about the VCLT, Art. 31(3)(c) in for example Benn McGrady, 'Fragmentation of International Law or "Systemic Integration" of Treaty Regimes: ECĐBiotech Products and the Proper Interpretation of Article 31(3)(c) of the Vienna Convention on the Law of Treaties' 42 (4) Journal of World Trade 589 (2008); Campbell McLachlan, 'The Principle of Systemic Integration and Article 31(3)(C) of the Vienna Convention' 54 International and Comparative Law Quarterly 279 (April 2005).

${ }^{45}$ Fragmentation of International Law: Difficulties Arising from the Diversification and Expansion of International Law, Report of the Study Group of the International Law Commission at its fifty-eighth session, finalized by Martii Koskenniemi, UN Document A/CN.4/L.682, para. 415. See about the obligatory requirement, the International Law Commission DRAFT ARTICLES to VCLT para. 9 re Art. 27.

46 WTO Appellate Body Report, United States - Standards for Reformulated and Conventional Gasoline (US Gasoline), WT/DS2/AB/R, adopted 20 May 1996, p. 17.

47 WTO Appellate Body Report, United States - Definitive Anti-Dumping and Countervailing Duties on Certain Products from China (US - Anti-Dumping and Countervailing Duties (China)), WT/DS379/AB/R, adopted 25 March 2011, para 304.
} 
obligations and 'a consistent and harmonious approach to the interpretation of WTO law among all WTO Members. ${ }^{48}$ Thus the VCLT requires that rules of international law which represent nontrade values must serve as interpretative context if they are relevant to the interpretation of the respective WTO provisions. According to the $\mathrm{AB}$, a rule of international law is relevant if it 'concerns the subject matter of the provision at issue. ${ }^{49}$ For example if some WTO Members have specified trade relations between them in a bilateral agreement it can serve as interpretative tool. However, the argument can be taken further; if a WTO provision potentially can be at odds with a rule of international law, the $\mathrm{AB}$ should seek an interpretation of the WTO provision which will harmonize with the rule of international law in order to avoid conflict.

A closer look at $\mathrm{AB}$ jurisprudence reveals that the $\mathrm{AB}$ only rarely looks outside the WTO framework. For example, the $\mathrm{AB}$ referred to other treaties in EC - Asbestos to establish facts and in $U S$ - Shrimps as interpretative tools. ${ }^{50}$ Apart from that, other international treaties only play a limited role in $\mathrm{AB}$ jurisprudence. For example, the $\mathrm{AB}$ has never referred to any human rights treaties. It must be mentioned that there has so far only been one case in the WTO which directly concerned human rights and which could have shed some light on the role of human rights in the WTO. In US - Procurement, the EU and Japan questioned the Massachusetts practice of rejecting companies, which were doing business with Myanmar (Burma), from qualifying to submit bids on public procurements. One reason for rejecting such companies' bids was the lack of human rights protection in Myanmar (Burma). The EU and Japan claimed that the Massachusetts practice violated the Agreement on Government Procurement as the qualification of suppliers was based on political rather than economic considerations. Later, the EU and Japan requested the Panel to suspend the panel proceedings and the case expired. ${ }^{51}$ Even though human rights only have been mentioned in US - Procurement, it does not mean that there have not been situations with potential overlaps between WTO law and human rights. In China - Publications and Audiovisual Products, the $\mathrm{AB}$ did not take the opportunity to include a human rights dimension in its interpretation of WTO law. ${ }^{52}$ The case concerned China's import restrictions on publications and audiovisual

\footnotetext{
${ }^{48}$ WTO Appellate Body Report, European Communities - Measures Affecting Trade in Large Civil Aircraft (EC and Certain Member States - Large Civil Aircraft), WT/DS316/AB/R, adopted 1 June 2011, para. 845. See the ICJ in Oil Platforms (Islamic Republic of Iran v. United States of America), Judgment, I.C.J. Reports 2003, p. 161, para. 41; 'The application of the relevant rules of international law (...) forms an integral part of the task of interpretation'.

49 Para. 848.

50 WTO Appellate Body Report, European Communities - Measures Affecting Asbestos and Products Containing Asbestos (EC - Asbestos), WT/DS135/AB/R, adopted 5 April 2001, and WTO Appellate Body Report, United States Import Prohibition of Certain Shrimp and Shrimp Products (US - Shrimps), WT/DS58/AB/R, adopted 6 November 1998. See more in section IV.

51 See Request for Consultations by the European Communities and Japan, United States - Measure Affecting Government Procurement (US - Procurement), WT/DS88/1, GPA/D2/1 of 26 June 1997, and WT/DS95/1, GPA/D3/1 of 21 July 1997, panel lapsed. The Massachusetts Burma Law was later found to be unconstitutional by the US Supreme Court because 1) the President of the US, not Massachusetts, had the authority to control sanctions against Burma, 2) the US Congress intended to reduce the level of economic sanctions against Burma, and 3) the President of the US had authority to develop a strategy concerning Burma with other States on a multilateral level. See Crosby v. National Foreign Trade Council, 530 U.S. 363 (2000).

52 WTO Appellate Body Report, China - Measures Affecting Trading Rights and Distribution Services for Certain Publications and Audiovisual Entertainment Products (China - Publications and Audiovisual Products), WT/DS363/AB/R, adopted 19 January 2010.
} 
products. China limited the right to import reading material, audiovisual home entertainment products, sound recordings, and film to state-owned enterprises and prohibited foreign-invested enterprises and private companies from importing such products. The restrictions violated the national treatment obligations under both GATT 1994, Art. III and GATS, Art. XVII. China claimed that the restrictions were justified under GATT 1994, Art. XX to protect public morals as there was a general prohibition of publication of violent and obscene material in China. ${ }^{53}$ Even though the restrictions could be justified in order to protect public morals the measures did not pass the necessity test. ${ }^{54}$ The AB referred to previous AB findings where 'necessary' must be established on basis of the level of contribution the measures make to the protection of 'public morals' and that it must be based on evidence or data pertaining to the past or present. ${ }^{55}$ The AB did not discuss GATT 1994, Art. XX in light of human rights. Even though public morals may justify the restriction of media which can carry violent and obscene expressions, such restrictions can be a limitation of freedom of expression. ${ }^{56}$ If Art. 31(3)(c) of the VCLT and its preamble are taken into consideration, it may be asked whether the policy objectives in GATT 1994, Art. XX and GATS, Art. XIV should be interpreted in light of international human rights instruments when there are such potential overlaps between WTO law and human rights. After all the preamble of the VCLT provides for the observance of human rights and fundamental freedom for all and most of the WTO Members are bound by the ICCPR and/or ICESCR. Human rights will be further addressed in section IV. However, neither the US nor any of the third parties in China - Publications and Audiovisual Products referred to human rights. It is a general observation from disputes in the WTO that human rights considerations are not included by the disputing parties, third parties, panels or $\mathrm{AB} .^{57}$

\section{The AB and Explicit Exceptions}

GATT 1994, Art. XX encompasses a list of exceptions to the basic trade principles. ${ }^{58}$ The AB has stated that the list of exceptions is exhaustive. ${ }^{59}$ Thus Art. XX can only protect those values which

\footnotetext{
${ }^{53}$ See more about 'public morals' in GATT 1994, Art. XX (a) and GATS, Art. XIV (a) below. In the specific case, China did not invoke GATS, Art. XIV (a) to justify the measures which the panel had found to be inconsistent with GATS Art. XVI and Art. XVII.

54 The US did not dispute the argumentant that violent and obscene material can be justified under GATT 1994, Art. $\mathrm{XX}(\mathrm{a})$.

${ }^{55}$ Paras 251-252. See more below in section IV.

${ }^{56}$ China has not ratified the ICCPR. However, the UN Human Rights Council, which promotes human rights as well as makes recommendations to the General Assembly for the further development of human rights, undertakes periodic reviews of the UN Member States on a general level, including reviews of their conformity with principles of those human rights treaties which are not ratified by the State under review. See for example the recommendation by the working group on the periodic universal review of China and the ICCPR, A/HRC/11/25, 5 October 2009, para. 114. See also Ernst-Ulrich Petersmann, above n 28, at 269-270.

${ }^{57}$ Other international courts also avoid the human rights dimension. See for example The Arctic Sunrise Case, where the International Tribunal for the Law of the Sea (ITLOS) left out any discussion on the human rights argument forwarded by the Netherlands that Russia violated Art. 9 and Art. 12 of the ICCPR. The ITLOS based its legal argumentation on the UN Convention on the Law of the Sea; the Arctic Sunrise Case (Kingdom of the Netherlands $v$. Russian Federation) Provisional Measures, Order of 22 November 2013, ITLOS Reports 2013. See in contrast the dissenting opinion delivered by Judge Kulyk who includes the human rights dimension, para. 12.

${ }^{58}$ GATT 1994, Art XX has other qualifications than the listed policy objectives. The chapeau of Art. XX requires that the measures restricting trade must not be applied in a manner which would constitute a means of arbitrary or
} 
can be subsumed under at least one of the explicit policy objectives. ${ }^{60}$ As mentioned above, the AB will on rare occasions seek guidance from other sources of law and international organizations in order to give meaning to and define the scope of the non-trade policy objectives. For example in $E C$ - Asbestos, the AB referred both to the WHO and the International Agency for Research on Cancer in support of the view that chrysotile asbestos fibres and chrysotile-cement products pose a risk to human health, ${ }^{61}$ and in US - Shrimp, the AB referred to the 1982 United Nations Convention on the Law of the Sea and the Final Act of the Conference to Conclude a Convention on the Conservation of Migratory Species of Wild Animals in defining exhaustible natural resources. ${ }^{62}$ Also in US Shrimp, the AB included a temporal dimension; according to the AB, the term 'exhaustible natural resources' was 'actually crafted more than 50 years ago. They must be read by a treaty interpreter in the light of contemporary concerns of the community of nations about the protection and conservation of the environment. ${ }^{63}$ The interpretative approach by the $A B$ is open-ended in the sense that the policy objectives are flexible to contemporary ideas and understandings in the context of other international organizations.

In contrast to the closed list in GATT 1994, the Agreement on Technical Barriers to Trade (TBT) provides an open list. It permits WTO Members to apply technical regulations which may concern product characteristics or processes and production methods as well as terminology, symbols, packaging marking or labelling requirements. ${ }^{64} \mathrm{~A}$ technical barrier to trade must pursue 'legitimate

unjustifiable discrimination between countries where the same conditions prevail, and they must not be a disguised restriction on international trade. Those requirements are very interesting but outside the scope of this article.

${ }^{59}$ Appellate Body Report, US - Gasoline, above n 46, p. 22. See about the TBT Agreement below.

${ }^{60}$ For example, in respect of 'public morals', the AB has recognised that 'public morality' may vary from state to state due to differences in social, cultural, ethical and religious values and that there must be some scope for the WTO Members to decide their respective public morals, see WTO Appellate Body Report, European Communities Measures Prohibiting the Importation and Marketing of Seal Products (EC - Seal Products), WT/DS400/AB/R and WT/DS401/AB/R, adopted 18 June 2014, paras 5.199-5.200, referring to the WTO Panel Report, United States Measures Affecting the Cross-Border Supply of Gambling and Betting Services (US - Gambling), WT/DS285/R, paras 6.461-6.465. Under the public morals category the AB has accepted animal welfare and prohibition against publications of violent and obscene material as well as material propagating hatred and discrimination; see Appellate Body Report, EC - Seal Products and Appellate Body Report, China - Publications and Audiovisual Products, above $\mathrm{n}$ 52, para 243, referring to the panel report, paras. 7.760-7.763. The category of 'exhaustible resources' has been applied to protect clean air and sea turtles, see for example Appellate Body Report, US - Gasoline, above n 46, although it is implied in the obiter dicta, and Appellate Body Report, US - Shrimps, above note 50. Protection of human life and health has been applied to protect national measures against chrysotile-cement products and measures against waste tyres causing dengue fever and malaria, see for example Appellate Body Report, EC-Asbestos, above n 50, and WTO Appellate Body Report, Brazil - Measures Affecting Imports of Retreaded Tyres (Brazil - Retreaded Tyres), WT/DS332/AB/R, adopted 17 December 2007. 'Secure compliance with laws or regulations' has been applied to protect measures countering tax evasion and smuggling. See for example WTO Appellate Body Report, Dominican Republic - Measures Affecting the Importation and Internal Sale of Cigarettes (Dominican Republic - Import and Sale of Cigarettes), WT/DS302/AB/R, adopted 19 May 2005.

${ }^{61}$ Appellate Body Report, EC - Asbestos, above n 50, para. 162. See also WTO Appellate Body Report, United States Measures Affecting the Production and Sale of Clove Cigarettes (US - Clove Cigarettes), WT/DS406/AB/R, adopted 24 April 2012, where the AB referred to the WHO in support of the view that WTO Members may implement public health policies and tobacco control and prohibit or restrict certain ingredients in tobacco products, paras. 11 and 235 236.

${ }^{62}$ Appellate Body Report, US - Shrimp, above n 50, para. 130.

${ }^{63}$ Ibid., para. 129.

${ }^{64}$ TBT Agreement, Annex 1. This is an area where the dichotomy into 'trade' and 'non-trade' is not that obvious. For example, labelling is a means to reduce asymmetrical information between the producer and the consumer. 
objectives' which 'inter alia' are protection of human, animal or plant life or health, protection of the environment, or prevention of deceptive practices. ${ }^{65}$ According to the $\mathrm{AB}$, the list is not exhaustive. If the 'legitimate objective' is not listed, it must be an aim or target 'that is lawful, justifiable, or proper. ${ }^{66}$ Such lawful, justifiable or proper aim or target may be one of the objectives mentioned in one of the other WTO treaties, like GATT 1994, Art. XX. ${ }^{67}$ The AB does not provide further guidance on legitimate objectives outside the texts of the WTO treaties and it may indicate that the $\mathrm{AB}$ will not read further legitimate objectives into the TBT Agreement than those mentioned in the WTO treaties. ${ }^{68}$

It is unsettled in $\mathrm{AB}$ practice how those non-trade values, which are underlying peremptory norms and human rights, should be approached. In respect of peremptory norms, one route to take is to regard such norms as higher ranking per se due to their peremptory nature. The trade principles must conform to the peremptory norms. Thus it is not a matter of derogation from the basic trade principles. The interpretation of WTO provisions must in no way lead to a result where peremptory norms are violated. Another route to take is to accept such norms under the exceptions in the treaties where they must fall under one of the explicit non-trade policy objectives. The problem with that approach is that before the exception is applied, there must in the first place have been a violation of one of the WTO trade rules. If the violation of the trade rule is a result of a WTO Member's compliance with peremptory norms, there is a conflict between the WTO rule and the peremptory norm where the latter should prevail. ${ }^{69}$ The exceptions might be better suited for such human rights which do not qualify as peremptory norms.

It is here worth noting that the $\mathrm{AB}$ in its necessity analyses has opened the door to rank non-trade values in accordance to their 'importance' ${ }^{70}$ GATT 1994, Art. XX (a), (b), and (d) provide that the national measures must be 'necessary' in order to protect the particular policy objective. ${ }^{71}$ In Korea - Various Measures on Beef, the AB stated that the necessity analysis 'involves in every case a process of weighing and balancing a series of factors which prominently include the contribution made by the compliance measure to the enforcement of the law or regulation at issue, the importance of the common interests or values protected by that law or regulation, and the

\footnotetext{
65 TBT Agreement, Art. 2.2.

${ }^{66}$ WTO Appellate Body Report, United States - Certain Country of Origin Labelling (COOL) Requirements (US COOL), WT/DS384 and WT/DS386/AB/R, adopted 23 July 2012, para. 370 and WTO Appellate Body Report, United States - Measures Concerning the Importation, Marketing and Sale of Tuna and Tuna Products (US - Tuna II (Mexico)), WT/DS381/AB/R, adopted 13 June 2012, para. 313.

${ }^{67}$ Ibid.

${ }^{68}$ See also para. 314 in US - Tuna II (Mexico), ibid, which provides that a panel must follow the guidelines provided by the AB in para. 313. Thus it would be difficult for a panel to read other legitimate objectives into the TBT Agreement without stepping outside those AB guidelines.

${ }^{69}$ See also VCLT Art. 53 which renders the trade rule void if it conflicts with peremptory norms.

${ }^{70}$ See for a thorough exam of the proportionality test applied in the WTO, Mads Andenas and Stefan Zleptnig, 'Proportionality: WTO Law: In a Comparative Perspective', 42 (3) Texas International Law Journal 371 (2007).

${ }^{71}$ GATT 1994, Art. XX provides different qualifications between the respective policy objectives and the national measures where 'necessary' is one of them. The others are 'relating to' in Art. XX (c), (e), and (g), 'in pursuance of' in Art. XX (h), 'essential' in Art. XX (j), 'for the protection of' in Art. XX (f), and 'involving' in Art. XX (i).
} 
accompanying impact of the law or regulation on imports or exports. ${ }^{72}$ In Brazil-Retreaded Tyres, the $\mathrm{AB}$ refined its approach. Referring to $U S$ - Gambling, the $\mathrm{AB}$ stated that the weighing and balancing process inherent in the necessity analysis "begins with an assessment of the 'relative importance' of the interests or values furthered by the challenged measure", and also involves an assessment of other factors, which will usually include "the contribution of the measure to the realization of the ends pursued by it" and "the restrictive impact of the measure on international commerce". ${ }^{73}$ In the particular case, the AB supported the panel finding that protection of human health and life against dengue fever and malaria is vital and important in the highest degree and the aim of protecting the environment is important. ${ }^{74}$ Apparently, the level of the necessity standard depends on the particular interest or value which the challenged measure seeks to protect. It is unclear on what basis the $\mathrm{AB}$ makes such 'importance' evaluation, ${ }^{75}$ but the ranking of non-trade values raises the question whether vital non-trade values require lower qualification in order to be subsumed under the explicit policy objectives than less important values. For example, the prohibition against 'work which, by its nature or the circumstances in which it is carried out, is likely to harm the health, safety or morals of children' in the Worst Forms of Child Labour Convention, Art. 1 and Art. 3(d) protects vital values of health, safety and morality of children. It should be basis for an importing WTO Member to reject products produced in violation of that rule. The question is whether GATT 1994, Art. XX (b) can be applied by an importing WTO Member towards products from those countries which violate the Worst Forms of Child Labour Convention or if it is limited to only cover the health of people within own territory. If Art. XX (b) does not apply, a prohibition has a legal basis under the 'public morals' exception in Art. XX (a). The public morals exception has some flexibility as it leaves some room for national differences in social, cultural, ethical and religious values. ${ }^{76}$ This position, however, leads to jurisdictional issues; if a WTO Member can impose import bans on products due to their process of production, including the conditions for workers, instead of the characteristics of the products, WTO Members may impose their own public morality standards on other states. The AB will most likely look for some connection between the object being protected and the importing state. In US - Shrimp, the AB

\footnotetext{
${ }^{72}$ WTO Appellate Body Report, Korea - Measures Affecting Imports of Fresh, Chilled and Frozen Beef (Korea Various Measures on Beef), WT/DS161 and 169/AB/R, adopted 10 January 2001, para. 164. See also Appellate Body Report, Brazil - Retreaded Tyres, above n 60, paras. 141-143.

${ }^{73}$ Appellate Body Report, Brazil - Retreaded Tyres, above n 60, para. 143, citing WTO Appellate Body Report, United States - Measures Affecting the Cross-Border Supply of Gambling and Betting Services (US - Gambling), WT/DS285/AB/R, adopted 20 April 2005, para. 306, which concerned the interpretation of GATS Art. XIV, which is applicable to the interpretation of GATT Art. XX.

${ }^{74}$ Para. 179. Where the $\mathrm{AB}$ has ranked policy objectives under the necessary test, it is different with the 'relating' test. The concept of 'relating' is linked to more economic-oriented policy objectives, like the one mentioned above about the conservation of exhaustible natural resources, where extinction of such resources is an irreversible cost to society with no possibility to recover for future production. Hence those policy objectives might by their underlying economic values already be regarded as important. 'Relating' is interpreted more flexible than 'necessary' by the AB, see for example Appellate Body Report, Korea - Various Measures on Beef, above n 72, footnote 104.

${ }^{75}$ See for a critique of this approach Robert Howse and Elisabeth Turk, 'The WTO Impact on Internal Regulations: A Case Study of the Canada - EC Asbestos Dispute', in Gráinne De Búrca and Johanne Scott (eds), The EU and the WTO - Legal and Constitutional Issues, (Oxford: Hart Publishing, 2001), 283-328 at 325-327.

${ }^{76}$ Appellate Body Report, EC - Seal Products, above n 60, paras 5.199-5.200. See also Robert Howse, 'The World Trade Organization and Protection of Workers' Rights', 3 The Journal of Small and Emerging Business Law 131 (1999)
} 
found that there was sufficient connection between the endangered species of sea turtles and the US to justify that US measures prohibiting import of shrimps, harvested in a manner which affected sea turtles, could qualify under Art. XX (g). ${ }^{77}$ The AB did not consider whether Art. XX (g) contains a limitation on jurisdiction but held that sea turtles are known for migrating to waters subject to US jurisdiction. Similarly in EC-Seal Products, where a ban on sale of products from seal was based on animal welfare; the EU claimed that hunts of seals are inhumane and that the public of the EU was repelled ethically and morally by such hunts. ${ }^{78}$ Without ruling on jurisdictional issues, the $\mathrm{AB}$ referred to the preamble of the contested EU Regulation which addressed seal hunting within and outside the EU and that seal welfare was of concern of EU citizens and consumers. ${ }^{79}$ In a footnote, the $\mathrm{AB}$ referred to the disputing parties' agreement that there was sufficient nexus between on the one side the public moral and the contested measures and on the other side the EU. ${ }^{80}$ As suggested by Howse, there is nothing in the text of Art. XX suggesting that it cannot be applied to such situations. ${ }^{81}$ In addition, the above-mentioned cases indicate that the tie between the policy objective and the importing state follows a low standard; sea turtles may migrate to US territory and even though the AB did not address the issue directly in EC - Seal Products, it still referred to the aims of the particular EU Regulation which applied to seal products from within and outside the EU. Hence the $\mathrm{AB}$ might be able to connect the working conditions for children and the importing state through the importing state's obligations under the Worst Forms of Child Labour Convention. In addition, those situations in the Worst Forms of Child Labour Convention which are prohibited under peremptory norms of public international law are linked to the states due to their universal nature and importance to the international community as a whole. ${ }^{82}$

The role of vital values, which underlie peremptory norms, and their place in the WTO system still has to be addressed by the $\mathrm{AB}$. The same goes for human rights in general. The $\mathrm{AB}$ has not provided answers to their role in relation to, for example, the exception in GATT 1994, Art. XX(a). In respect of non-trade values in general, the $\mathrm{AB}$ has developed a methodology where they are ranked in accordance to their 'importance', the $\mathrm{AB}$ has taken a flexible approach to the legitimate non-trade policy objectives, and the $\mathrm{AB}$ has applied a low standard for linking national measures with the particular object which is protected by national measures. Thus the AB has developed space where it can include a broad range of non-trade values under the exceptions.

\section{Protection of Non-Trade Values Outside the Exceptions}

The $\mathrm{AB}$ has also made space for non-trade values without reference to explicit exceptions in the WTO treaties. The justification is found in a market-based language by the AB. This section looks into two areas where the $\mathrm{AB}$ has made space for non-trade values without specific basis in the exceptions. One area is national treatment. The other area concerns the AB approach to subsidies.

\footnotetext{
${ }^{77}$ Appellate Body Report, US - Shrimps, above n 50, para 133.

${ }^{78}$ See Panel Report, EC - Seal Products, WT/DS400 and WT/DS401/R, para 7.4.

${ }^{79}$ Appellate Body Report, EC - Seal Products, above n 60, para 5.173.

${ }^{80}$ Ibid, footnote 1191.

${ }^{81}$ Robert Howse, above n 76, at 143-144.

${ }^{82}$ See Theodore Meron, above n 36, at 1.
} 


\section{a. National Treatment and Trade Limitations}

There is a balance to be struck between on the one side a WTO Member's right to regulate areas of concern, like human health, environment, criminal law, as well as right to establish rules governing ownership and on the other side the aim of the WTO to break down trade barriers. ${ }^{83}$ National treatment is a fundamental principle of WTO law and a core element in facilitating trade between the WTO Members. However, national treatment does not take away the WTO Members' rights to legislate in areas of concern and to adopt their specific ownership regime as long as they do not discriminate between national and foreign products.

As mentioned above, the AB dealt with questions about 'human health' in relation to GATT 1994, Art. $\mathrm{XX}(\mathrm{b})$ in EC-Asbestos. In the same case, the AB also made human health considerations in its 'like product' analysis of GATT 1994, Art. III.4. The panel had found that cement-based products containing PCG fibres and cement-based products containing asbestos were 'like' products. The analysis by the panel had a particular focus on the end-use of the products. According to the panel there was no difference. Furthermore, the panel found that the products could replace each other. The panel rejected the argument put forward by the EC that human health considerations should be taken into account in the 'like product' analysis as it would render the exceptions in Art. XX(b) useless. The $\mathrm{AB}$ disagreed with the panel. According to the $\mathrm{AB}$, the risk associated with asbestos is a matter of evidence. The text of Art. III.4 does not suggest that any evidence should be excluded from the 'like product' analysis. However, the health risk is not a separate criterion in the like product analysis. Rather, health risk is evidence which can be taken into account under the physical property and consumers' taste and habits criteria in Art. III.4. ${ }^{84}$ In the particular case, the AB found that the health risk associated with asbestos was a physical element and relevant under the physical property criterion. ${ }^{85}$ Furthermore, the $\mathrm{AB}$ was persuaded that consumer behaviour is different towards a product carrying health risk compared to a product without such risks. ${ }^{86}$ Health risk evidence is 'relevant in assessing the competitive relationship in the marketplace between allegedly "like" products' (emphasis by the $\mathrm{AB}) .{ }^{87}$ The $\mathrm{AB}$ then reversed the 'like product' findings by the panel.

The AB approach in EC-Asbestos has been transplanted into other WTO treaties. For example, in US - Clove Cigarettes, the US Federal Food, Drug and Cosmetic Act prohibited cigarettes with special flavours like clove. The Act did not prohibit regular cigarettes or menthol cigarettes. The aim of the prohibition was to reduce youth smoking. Cigarettes with special flavours were in particular popular among young people in social gatherings. Indonesia, which exported clove cigarettes to the US, made a complaint against the US asserting that the US violated the national treatment obligation of Art. 2.1 of the TBT Agreement and Art. III.4 of GATT 1994. The panel had in its national treatment assessment based its 'like product' analysis of Art. 2.1 of the TBT and Art. III.4 of GATT 1994 between clove cigarettes and menthol cigarettes on physical characteristics,

\footnotetext{
${ }^{83}$ Appellate Body Report, US - Clove Cigarettes, above n 61, para 109.

${ }^{84}$ Para. 113.

${ }^{85}$ Para. 114.

${ }^{86}$ Para. 122.

${ }^{87}$ Para. 115.
} 
end-uses, consumer tastes and habits, and tariff classification in light of the regulatory objectives. The panel found that clove cigarettes and menthol cigarettes were 'like' each other and the panel found that the imported cigarettes were given a less favourable treatment than the domestic products. The $\mathrm{AB}$ upheld the panel decision although for different reasons. It referred to $E C-$ Asbestos, and stated that the 'like product' analysis, including the regulatory concerns underlying the national measures like human health concerns, can be useful to the national treatment assessment under Art. 2.1 of the TBT Agreement if they have an impact on the competitive relationship between the products. ${ }^{88}$ The panel had failed by determining the likeness between the products in light of the regulatory objective instead of the competitive relationship between the products. ${ }^{89}$ Thus the regulatory concerns must be seen in light of the competitive environment. Human health is not in itself a sufficient reason; the only reason to protect human health must be found in the economic language of the competitive relationship between the products. ${ }^{90}$ Nevertheless, the approach by the $\mathrm{AB}$ in EC-Asbestos and US - Clove Cigarettes indicates that through the economic language there is space for the WTO Members to protect non-trade values without resorting to explicit exceptions.

The AB has in also its interpretation of the Agreement on Trade-Related Aspects of Intellectual Property Rights (TRIPS) indicated that WTO Members can impose trade restrictions which may hit specific WTO Members without violating the national treatment obligation. In US - Section 211 Appropriations Act, ${ }^{91}$ the EC claimed that US trademark law violated TRIPS and the Paris Convention for the Protection of Industrial Property, as amended by the Stockholm Act of 1967 (Paris Convention (1967)). ${ }^{92}$ The US applied special rules towards trademarks which had been confiscated by the Cuban government. Section 211 of the Omnibus Appropriateion Act provided that such trademarks could not be registered and enforced 'unless the original owner of the mark, trade name, or commercial name, or the bona fide successor-in-interest has expressly consented.' The EC claimed that the consent requirement prevented existing trademark owners from enjoying their rights and it was an obstacle to register new trademarks and therefore violated Art. 15 of TRIPS which defines a trademark. The AB stated that the US legislation concerned 'ownership' which is not regulated in TRIPS or the Paris Convention (1967). In addition, Art. 15(2) provides that a WTO Member may reject registration of a trademark on other grounds than those relating to the definition of a trademark as long as they do not derogate from the Paris Convention (1967). For example, Art. 6quinquies of the Paris Convention (1967) contains ordre public exceptions. The EC claimed that none of the exceptions in the Paris Convention (1967) could apply to the consent requirement in the US rules. The explicit exceptions in TRIPS and the Paris Convention (1967) were not disputed. The question was whether there are other exceptions than those mentioned in TRIPS and the Paris Convention (1967). With basis in Art. 6 (1) of the Paris Convention (1967), the $\mathrm{AB}$ found that it is left to the WTO Members to determine the conditions for filing and registration.

\footnotetext{
${ }^{88}$ Para. 119.

${ }^{89}$ Para. 136.

${ }^{90}$ If human health cannot be protected through the economic approach, the WTO Member must resort to the exceptions.

${ }^{91}$ WTO Appellate Body Report, United States - Section 211 Omnibus Appropriations Act of 1998 (US - Section 211 Appropriations Act), WT/DS176/AB/R, adopted 1 February 2002.

${ }^{92}$ It follows from Art. 2 of TRIPS that it must comply with the Paris Convention (1967).
} 
Thus, a WTO Member can impose requirements like the consent requirement without violating TRIPS and the Paris Convention (1967). ${ }^{93}$ In addition, the WTO Members can choose their specific rules governing ownership. It opens up for rules, like the US rules, where confiscation of trademarks by another state eliminates the intellectual property rights associated with those trademarks. ${ }^{94}$ The $\mathrm{AB}$ went on and examined whether the US had violated the national treatment principle enshrined in Art. 3.1 of TRIPS and Art. 2(1) of the Paris Convention (1967). Here the AB noted that the national treatment obligation requires WTO Members to accord 'no less favourable treatment to non-nationals than to nationals in the "protection" of trade-related intellectual property rights' ${ }^{95}$ The $\mathrm{AB}$ then referred to its analysis about ownership and stated that neither TRIPS nor the Paris Convention (1967) requires a WTO Member to adopt a particular ownership regime. ${ }^{96}$ Thus, the WTO Members can establish rules about how to acquire as well as how to lose ownership over intellectual property. TRIPS engages to some extent with rights of the owners of intellectual property like the exclusive rights of the trademark owner to prevent third-parties from using the trademark without the consent of the trademark owner, ${ }^{97}$ but it is silent about a situation like the one in US - Section 211 Appropriations Act. Even though WTO law does not interfere into the national ownership regimes, the different political, economic and cultural ideologies underlying the respective ownership regimes seem to justify a rejection of trade under WTO law. In this case WTO law justifies a state's rejection of enforcing the rights associated with trademarks if they have been confiscated from private companies by a state with a Communist rule.

\section{b. Negative Externalities and Protection of Non-Trade Values}

As mentioned above, negative externalities, like pollution, provide inefficient economic outcomes due to increased social costs. The private gain does not outweigh the costs of life, health or the cost of sustaining exhaustible resources which otherwise are damaged by pollution. Hence the market itself cannot provide the efficient outcome and it is necessary with governmental intervention. The $\mathrm{AB}$ has referred to negative externalities as legitimate reason to protect non-trade values. CanadaRenewable Energy and Canada - Feed-In Tariff Program concerned the feed-in tariff (FIT) programme in Canada which allegedly was a subsidy in violation of the Agreement on Subsidies and Countervailing Measures (SCM Agreement). The FIT programme guaranteed suppliers of electricity a fixed price by the Government if the supply of electricity was based on renewable energy. The SCM Agreement does not contain a list of non-trade policy objectives which can justify a subsidy. ${ }^{98}$ A subsidy exists 'if there is a financial contribution by a government or any public

\footnotetext{
93 The US violated both the national treatment principle and most favoured nation principle in TRIPS Art. 3(1) and Art. 4 as Cuban nationals faced more administrative steps than US nationals and other nationals.

${ }^{94}$ Para. 195.

95 Para. 243.

${ }^{96} \mathrm{Ibid}$. However, in the specific case, the US had violated the national treatment obligation because they imposed extra procedural hurdles on Cuban nationals than US nationals.

${ }^{97}$ Art. 16 of TRIPS.

${ }^{98}$ See however the SCM Agreement, Art. 8(2)(c): 'Notwithstanding the provisions of Parts III and V, the following subsidies shall be non-actionable (...) assistance to promote adaptation of existing facilities to new environmental requirements imposed by law and/or regulations which result in greater constraints and financial burden on firms'. Art. 8 expired in 1999.
} 
body within the territory of a Member' (...) and 'a benefit is thereby conferred.' 99 The AB stated that in order to determine whether a benefit had been conferred, it should be determined whether the financial contribution by the government was on more favourable terms for the recipient than those terms provided by the market. ${ }^{100}$ Hence the relevant market had to be defined. The question was whether the relevant market was a general market for electricity or a narrow market for electricity based on renewable energy. In the case of the latter, a benefit would not be conferred if all the suppliers of electricity based on renewable energy could be part of the FIT programme. Canada held that the relevant market was the market for electricity produced from solar PV and windpower technology, i.e. renewable energy, whereas Japan and the EU claimed that the relevant market was the general market for electricity. At the panel stage, the Panel had agreed with Japan and the EU. According to the Panel, the consumers of electricity in Ontario did not distinguish between electricity on the basis of different generation technologies. ${ }^{101}$ The AB criticized the Panel's market definition as the Panel had not considered the supply side and the Panel's analysis of the demand side had not included several factors which may differentiate the markets, like the type of contract, the size of the customer, and the type of electricity generated (base-load versus peak-load). According to the $\mathrm{AB}$, the 'supply-side factors suggest that windpower and solar PV producers of electricity cannot compete with other electricity producers because of differences in cost structures and operating costs and characteristics. ${ }^{102}$ Even though the final product, electricity, might be the same, it is necessary to distinguish between the sources of supply. ${ }^{103}$ Furthermore, the Panel had wrongly decided the demand side to be the consumers at the retail level. According to the $\mathrm{AB}$, the correct buyer was the Government of Ontario, which bought electricity on the wholesale level, and not the consumers at the retail level. The AB stated furthermore that the existence of the windpower and solar PV generation would be impeded without governmental interference. According to the $\mathrm{AB}$, the relevant market was therefore 'the competitive markets for wind- and solar PV-generated electricity, which are created by the government definition of the energy supply-mix,' not the general market for electricity. ${ }^{104}$

Turning to the question of the benefit benchmark for electricity produced from windpower and solar PV technologies, the AB continued its critique of the Panel's methodology. Even though the Panel initially defined the relevant market as the general electricity market, it found that 'competitive wholesale electricity markets, although a theoretical possibility, will only rarely operate in a way that remunerates the mix of generators needed to secure a reliable electricity system with enough revenue to cover their all-in costs, let alone a system that pursues human health and environmental

\footnotetext{
${ }^{99}$ SCM Agreement, Art. 1 (a)(1). The term 'benefit' of Art. 1 is clarified in Art. 14 (d).

100 Appellate Body Report, Canada - Renewable Energy and Canada - Feed-In Tariff Program, above n 22, para. 5.163. See also WTO Appellate Body Report, Canada-Measures Affecting the Export of Civilian Aircraft (CanadaAircraft), WT/DS70/AB/R, adopted 20 August 1999, para. 157

${ }^{101}$ Para. 7.318 in the panel report.

102 Para. 5.174. The AB noted that'Windpower and solar PV technologies have very high capital costs (as compared to other generation technologies).' Capital costs are fixed costs which the producer often just bears once. The AB further stated that windpower and solar PV technologies hardly have any economies of scale which means that the costs of producing will not decrease with an increase in production.

103 Ibid.

${ }^{104}$ Para. 5.178.
} 
objectives through the inclusion of facilities using solar PV and wind technologies into the supplymix. ${ }^{105}$ The Panel applied the language of the non-trade policy objectives in GATT 1994, Art. XX and GATS, Art. XIV and stated furthermore that a competitive wholesale market might not attract the needed investments to secure a reliable supply of electricity. The AB found that the approach by the Panel had no basis in the SCM Agreement as the Panel seemed to apply factors as 'reliable electricity system' and 'human health and environmental objectives' as exceptions to the market based rule in the SCM Agreement. The AB stated that an introduction of legitimate policy objectives could not be reconciled with the SCM Agreement but it did not exclude governments from intervening to 'create markets that would otherwise not exist.' 106 According to the AB, without such creation of a market by the government, there would be a risk that electricity would not be constant and reliable. From long term considerations, fossil energy resources would be exhaustible whereas renewable energy can provide reliable supply of electricity in the long run. ${ }^{107}$ It was necessary to distinguish between a government's intervention to create a new market, which logically could not be seen as a distortion on an existing market, and a government's intervention to support certain businesses on an existing market which could distort that market. ${ }^{108}$ Besides the long term considerations, which justified the invention of a new market, the AB stated that all costs, inclusive of externalities, should be included in the analysis. The higher-priced electricity from renewable energy provides positive externalities, like guaranteed long-term supply and it addresses environmental concerns, whereas the lower-priced electricity based on 'lower prices for nonrenewable electricity generation have certain negative externalities, such as the adverse impact on human health and the environment of fossil fuel energy emissions and nuclear waste disposal 109 (my emphasis). Hence the negative impact on non-trade values like human health and the environment caused by an existing market may justify that a government creates a 'new' market to internalize the negative externalities.

The case is interesting as the $\mathrm{AB}$ rejects human health and environment as legitimate reasons for departing from the SMC Agreement. That textual approach is not novel; as mentioned above, the AB does not read additional policy objectives into GATT 1994, Art. XX than those explicitly mentioned. Even though human health and the environment cannot be seen as legitimate exceptions in this case, it does not render them unprotected. The economic argumentation developed by the $\mathrm{AB}$ about externalities saved the day for the human health and environmental objectives. In line with the national treatment assessments, the $\mathrm{AB}$ has also in respect of subsidies found space to include non-trade values through its economic argumentation.

\section{Final Thoughts}

Human health has so far been protected in WTO law through the explicit policy objectives of the WTO treaties; in the 'like product' analysis; and as a value necessary to protect against market

\footnotetext{
105 Para. 7.309 in the panel report.

106 Para. 5.185.

107 Para. 5.186.

108 Para. 5.188.

109 Para. 5.189.
} 
failures. Even though the $\mathrm{AB}$ adopts different roads of argumentations, it can be asked whether human health has attained a high-ranking status which will be protected across the WTO system by the AB. After all, the AB has regarded human health as a vital value. The same question may be asked about environmental protection, which so far has been protected in the explicit exceptions of the WTO treaties and as a value necessary to protect against market failures. There is no reason to expect that environmental concerns cannot play a part in the 'like product' considerations as well. According to the $\mathrm{AB}$, the environment is an important value.

The method behind the ranking of values is so far left behind a curtain but it opens up for a question; has the $\mathrm{AB}$ put itself in a position where certain values cannot be ignored in the WTO system? Even though the ranking of non-trade values is part of the necessity test, and that the AB will not read other values into the WTO system than those which can fit into one of the explicit policy objectives, the consideration of the importance of the non-trade values will make it difficult for the $\mathrm{AB}$ to reject such vital values as enshrined in the Worst Forms of Child Labour Convention, ${ }^{110}$ in particular those which have status as peremptory norms of general international law like prohibition of slavery. ${ }^{111}$ The $\mathrm{AB}$ could find justification under the public morality protection in WTO law, the preamble of the WTO Agreement, and the 1996 Singapore Ministerial Conference Declaration, where the Ministerial Conference renewed its commitment to the observance of internationally recognized core labour standards, ${ }^{112}$ and thereby avoid the question of the hierarchic nature of peremptory norms and their role in WTO law. ${ }^{113}$ But how would the AB respond to a situation where such vital values do not have explicit protection as a legitimate policy objective under any of the WTO treaties like the case with the SCM Agreement? Would the AB be able to apply the economic language to justify governmental interference into the market - like the creation of a new market - if the particular governmental support aimed at businesses which could demonstrate that they carried out control of their suppliers' conformity with the principles reflected in the Worst Forms of Child Labour Convention? The answer must be negative. The AB would have to search for other routes than the market-based in order to avoid the indirect acknowledgment of a market for products produced by child slaves. ${ }^{114}$ Perhaps the AB would have to take the step in direction of peremptory norms and admitting them into its methodology and thereby opening the door to higher-ranking non-trade values in the WTO.

\footnotetext{
110 This writer implicitly acknowledges the absolute and fundamental character of the peremptory norms prohibiting slavery as stipulated in the convention.

111 See the ICJ about prohibition of slavery as erga omnes obligations in Barcelona Traction, Light and Power Company, Limited, Judgment, I.C.J. Reports 1970, p. 3, para. 32, and the Economic Community of West African States (ECOWAS) Community Court of Justice; Koraou v Niger, AHRLR 182 (ECOWAS 2008), paras. 75 and 81. See Theodore Meron, above n 36, at 11.

112 Singapore WTO Ministerial 1996: Ministerial Declaration, WT/MIN (96)/DEC, 18 December 1996.

${ }^{113}$ Please keep in mind the discussion above about the potential conflict between the trade rules and peremptory norms if the $\mathrm{AB}$ seeks justification for the trade restrictions under the exceptions.

${ }^{114}$ Such a market would be the comparative basis for the market with products not produced by child slaves.
} 